\title{
Psychiatry in Ancient Egypt
}

\author{
Mervat Nasser, Senior Lecturer in Psychiatry, University of Leicester, Clinical Sciences Building, \\ Leicester Royal Infirmary, Leicester
}

\begin{abstract}
"No artist attains total excellence, but the strength of truth and justice is that it lasts and that man can say ... this is the heritage of my father."

(Ptah - Hetep's maxim)
\end{abstract}

The ancient Egyptians called medicine the 'necessary art'. What is known about this art is documented mainly in nine principal papyri-Edwin Smith, Chester Beaty, Carlsberg, Kahoun, Rameseum, Leyden, London, Berlin and the Ebers. Considerable effort has been given over the years to present the sum of medical knowledge obtained from these papyri. Dr P. Ghalioungui's book Magic and Medical Science in Ancient Egypt ${ }^{1}$ is a rather recent contribution made by an Egyptian physician; he addresses issues related to the practice of pharaonic medicine with some references to psychiatry.

My aim here is to highlight and elaborate on these aspects, not only out of fascination for the subject, but also to convey how scarce medical literature is on this topic. It is also my attempt to pay tribute to a distinguished professor of medicine and medical historian who taught for many years in Ain Shams University, Cairo and who died last year.

\section{Knowledge of the brain}

Among medical papyri, the most relevant to psychiatry are the Ebers and the Edwin Smith papyri. Both were set down at approximately the same time, $1550 \mathrm{BC}$. The Edwin Smith is important because in it the brain is described for the first time in history as being enclosed in a membrane and that its hemispheres are patterned with convolutions.

The Ancient Egyptians recognised that the brain was the site of mental functions. They emphasised the importance of assessing the state of consciousness and memory in all routine examinations. The state of consciousness was commonly expressed in the following phrases:

the perishing of the mind (ib) $[\mathrm{Eb}, 855]$

the mind (ib) is forgetful like one who is thinking of something else [Eb, 855)]

the fleeting mind [Eb, 227]

his mind goes away [Eb, 227]

it is difficult for him to hear the spoken word [S, 21]

which seem to be rather comparable to the way the patient's concentration and attention is assessed and described in today's clinical examinations.

\section{Psychology in Ancient Egypt}

The Egyptians believed that every personality had a part which was the 'sum' of the real or inner self. This explains their belief in the principle of the two names, one is known and the other is hidden. The real name of an object was identified with the object itself.

"Nothing existed that had not received a name and who lost his name lost his personality and independence" (Maspero). ${ }^{2}$

This bears some resemblance to the Freudian concept of the 'unconscious' or the concept of the invisible in Gestalt psychology. The struggle to know the real name was symbolic of the struggle to know the unknown.

In Torino's papyrus he says, "I am he who has names... my mother and my father told me my name ... it is hidden since my birth in my body...."

The same papyrus relates how Isis, curious about the real name of her father, compelled him to reveal it by having him bitten by the snake she created.

The Egyptians employed a wide range of magical methods to avert possible harm or to cope with some inner fears. They are not unlike our modern concept of 'defence mechanisms'; for instance they used the principle of transfer in their medicament to get rid of migraine. The aching side of the head was rubbed with the head of a fish, to transfer the pain from the head of the sick to the head of the fish, using the fish somewhat as a scapegoat! ... "What carries off the disease." (Eb 250).

More interesting, however, is attacking one's enemies through manipulation of a figure made of wax or a doll which resembles the enemy, so displacing one's anger to a more amenable object. In fact this is still practised to this day in Egypt [Ley, 348, 12, 6]. The Ancient Egyptians also had ritualistic methods to ensure one's salvation from imminent troubles. These were done by reciting a certain formula to a certain number during an epidemic, e.g. "I am the one who has seen the great disaster ... I am the healthy one ... I am the one who has come out of the disaster." Apart from the attempt to assert oneself here, it is rather similar to the defence mechanism of 'undoing'. (S. XVIII 19.XSX).

Identification with the powerful or the aggressor was another defence used in Ancient Egypt. Many references are made to identification with the God himself.

"Beware, lest the God suffer ... for then will darkness fall, clouds will obscure the sky and water shall overspread to earth." (Ley, I, 348/verso 4, 3-4]

Mummification is by and large the most important and well known defence mechanism used by the Egyptians in relation to death. In fact, the word death is hardly mentioned in the ancient papyri ... to the Ancient Egyptian death was 
nothing but a further step in life which allowed his soul or 'ba' to return to his body and resume with it his interrupted life.

"I tell myself," says Stell, "this is convalescence after sickness like a man who goes out to catch birds and suddenly finds himself in an unknown country." Were the Ancient Egyptians unable to accept death? Their reaction was not just mummification of the deceased and his possessions. They also invested a great deal of effort in their elaborate system of funerary. Was it, then, their attempt to defy fate and assert an eternally continuing life against the finality of death?...

Interestingly enough, the Egyptians today are not all that different from their ancestors and part of their present mourning ritual is visiting the grave and taking with them the food the deceased used to like in his lifetime.

\section{Diseases of the Mind (ib)}

\section{Hysteria}

The Ancient Egyptians recognised the emotional disorder that the Greeks called hysteria. They believed that the symptoms were caused by malposition of the uterus and therefore fumigated the vagina ... hoping to restore the wandering vagrant uterus to its natural position. They thought that 'blindness' could be hysterical in nature and used the ritual of transfer to cure it, e.g. by placing the vitreous humor of a hog's eye in the ear of the patient and pronouncing twice a certain spell, supposed to exchange the blind eye for the healthy eye of an animal. [Eb 356]

Hysterical or mass fainting is another recognised symptom. It is beautifully depicted in Ank-Ma Hor's tomb. Fainting as a psychological symptom has been referred to in more than one instance....

“As for faintness ... the (ib) mind, faint" (Eb 855)

"As to the feeling of sickness ... the ib is sick" [Eb 855]

Another symptom often attributed to psychic factors is a headache which was again treated through the utilisation of the concept of transfer as mentioned before [Eb 253, 260, 247].

\section{Alcoholism}

Drunkenness is colourfully described in many poems:

"thou running from tavern to tavern, stinking of beer. Beer, when it invades a man, masters his soul."

"thou becomes like an oar, broken in its place that obeys neither side."

"though art like a chapel without its god, like a house with no bread and whose walls are rocking."

It is clear in these poems, the realisation of the effect of alcohol, not only on the body and soul but also on social life.

In the Insinger papyrus the hangover of the 'morning after' is mentioned using the French name 'hairache' (mal aux chevaux):
"He who with wine overfills himself, by aching hair to his bed will be kept"

which shows their degree of awareness of the withdrawal effects of alcohol.

\section{Sadness}

Athough the Egyptians did not give sadness a proper medical designation, they described it in depth in their papyri and gave to it some medical attributes. This is clearly illustrated in the illness of Satri Khamois:

"He huddled up in his clothes and lay, not knowing where he was, his wife inserted her hand under his clothes and said 'no fever in your chest, it is the sadness of the heart."'

In another description, the depressed man says:

"I feel my limbs heavy, I no longer know my own body, my eyes decline, my ears harden, my voice is speechless. Should the Master Physician come to me? My heart is not revived by their medicine."

In this description, sadness undoubtedly reached the proportion of an illness and manifested itself with a number of somatic complaints. It is this somatised form of depression that is still regarded to be the commonest presentation in Egypt today. Even suicide had been resorted to in certain instances. This sense of despair is beautifully illustrated in the following:

"Now death is to me like health to the sick, like the smell of a lotus, like the wish of a man to see his house after years of captivity."

The Ancient Egyptian had also a way of describing and recording mood changes, for example:

"The mind in the heart which goes up and falls down." [Eb 855]

"The mind kneels, his heart in its place, his heart becomes weary, he eats little and is fastidious." [Eb 855]

"His mind is drowned, this means his mind is forgetful, like one who is thinking of something else ... as if his mind is dark" [Eb 855]

\section{Who was the Ancient Egyptian poychiatrist?}

Herodutus said of Egypt. "There are physicians for the eyes, others for the hands, teeth, abdomen and for unknown diseases." Nevertheless, there is no mention of a physician who specialised in mental diseases. It is likely however, that the sorcerer in ancient Egypt was in fact the psychiatrist. The sorcerer was chosen with utmost care as he was going to be entrusted with dreadful secrets! The king himself in many instances combined the two functions.

The future sorcerer was elected at his birth either because he belonged to the sorcerer's clan or was of royal blood. He was then subjected to a rigid mode of life and numerous taboos, to the point of compelling him to hide his face by 
wearing a mask, discouraging, therefore, his transparency and enforcing his detachment and isolation. The training of the sorcerer aimed at sharpening his psychic functions and equipping him with exceptional perception.

The sorcerer had to convince people of his omnipotent powers, which meant that he had to know or follow certain rites. These may range from a simple gesture to complete dramatisation of the desired events. The peak is reached in the sacred drama or the magic religious dance. This was sometimes facilitated by hallucinogenic drugs like mescaline which indicates the Ancient Egyptian's knowledge of hallucinogens.

The psychodrama still lives and is practised in Egypt in the form of the 'zar dance'. The actual practice involves the gathering of a group of women who are believed to be possessed by spirits. The gathering is headed by a woman who acts as a leader and is called 'Kodia'. The Zar ceremony starts off with traditional music and dance, performed by a hired group of dancers who then urge the women patients to take part in the dance until they reach a point of exhaustion. The Kodia then approaches each individually and asks the devil inside her to leave his victim. The Zar cult has some similarity with the western concept of group psychotherapy. It is a group setting based on the notion of equal participation of the group members. It also provides a milieu for the expression of feelings through the dance.

The sorcerer was also accredited with the title 'the scribe of the house of life'-the Pir-ankh. It was said of him:

"you the scribe of the house of life, there is nothing on which you would be questioned to which you would not find an answer."

Another duty of the sorcerer was the interpretation of dreams. In fact, the designation 'the scribe of the house of life' acquired later in Coptic the meaning of the interpreter of dreams.

The Pir-ankh or house of life was used as a kind of retreat where the ill were prepared for their therapeutic dreams. Isolation, silence and dim light were the means to put the patient in a state of receptivity with the intention of unravelling the unknown. This practice is akin to hypnotherapy and was probably known to the Egyptians before the Greeks' therapeutic temples.
Another function of the 'house of life' was educational. It was the place where reading and teaching took place. Medical ethics were an essential component in the teaching of medical practice. The ethical code that governed the practice of medicine did not ignore the insane. I therefore conclude this article with the wise Amenhotep's words in this respect:

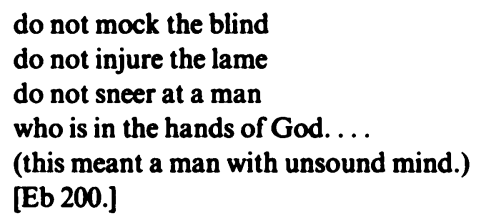

\section{PAPYRI}

Eb. The papyrus Ebers, Ebbell, B, Levin \& Munksgaard, Copenhagen 1937.

Ley. Le Papyrus de Leyde, 1347-1349, trad. et transer. Par A. Massey, Ghent, H. Engelcke, 1885-1886, Etudes Egyptalogiques, No 1-2.

S. The Edwin Smith Surgical papyrus, edited by Breastead, J. H. 1930, The Chicago University Press, Chicago.

The Chester Beaty VI Medical Papyrus. French translation by Jonckheere, F, La Medicine Egyptienne, No 2, Bruxelles, 1947, Fondation Egypt. Reine Elisabeth \& Gardiner, A. H., Hieratic papyri in the British Museum, 3rd series, No 53-54, London 1935.

The papyrus Insinger, Volten A, Das Demotische Weisheitsbuch, Analecta Aegyptiana, Copenhagen 1941, II

Torino Medical papyrus, Pleyte, W. et Rossi, F. Leyden 1869-1876.

\section{REFERENCES}

'Ghalloungul, P. (1963) Magic and Medical Science in Ancient Egypt. London: Hodder \& Stoughton.

2Maspero (1912) Guide du Visiteur au Musée del Caire. Printed by Inst. Fr. d'Arch Or, Cairo, IInd ed., 6, 507. 